IRA-Inte rnational Journal of Education \&

Multidisciplinary Studies

ISSN 2455-2526; Vol.07, Issue 03 (2017)

Pg. no. 235-239

Institute of Research Advances

http://research-advances.org/index.php/IJEMS

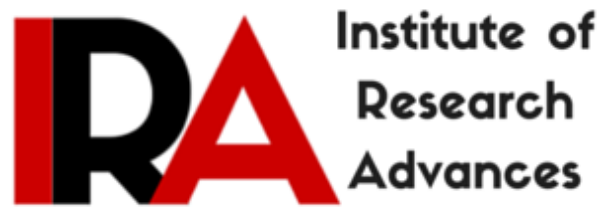

\title{
Effect of Teachers' Own Perception of Their Profession on Job Satisfaction and Performance in the Private Primary Schools in Yei Town, South Sudan
}

\author{
Alyaha Daniel Felix Ohide \\ Principal, Emmanuel Bible College, Goli - Yei, South Sudan, c/o Open Doors \\ P. O. Box 30870 - 00100, Nairobi, Kenya. \\ Rosemary Wahu Mbogo \\ Education, Arts and Social Sciences (SEAS), Africa International University \\ P.O. Box 24686 - 00502 Karen, Nairobi, Kenya.
}

Type of Re view: Peer Reviewed.

DOI: http://dx.doi.org/10.21013/jems.v7.n3.p8

\section{How to cite this paper:}

Alhaya, D. O., \& Mbogo, R. W. (2017). Effect of Teachers' Own Perception of Their Profession on Job Satisfaction and Performance in the Private Primary Schools in Yei Town, South Sudan. IRA International Journal of Education and Multidisciplinary Studies (ISSN 2455-2526), 7(3), 235-239. doi:http://dx.doi.org/10.21013/jems.v7.n3.p8

(C) Institute of Research Advances.

\section{(cc)) $\mathrm{BY}-\mathrm{NO}$}

This work is licensed under a Creative Commons Attribution-Non Commercial 4.0 International License subject to proper citation to the publication source of the work.

Disclaimer: The scholarly papers as reviewed and published by the Institute of Research Advances (IRA) are the views and opinions of their respective authors and are not the views or opinions of the IRA. The IRA disclaims of any harm or loss caused due to the published content to any party. 


\begin{abstract}
Teachers often find themselves frustrated at work because of conflicting expectations concerning their professional and social roles within the community. This paper looks at the effect of teachers' perception of their profession on their satisfaction at job and performance. The authors employ a survey design in private schools in Yei Town, South Sudan to establish the impact of these perceptions. Simple random sampling technique was used to select the respondents from ten private schools. The respondents' therefore included 10 head teachers, 100 teachers giving a total of 110 respondents. Questionnaires were used for data collection. Data collected was analysed by the use of Statistical Package for Social Science (SPSS) version 12.0 was and presented in frequencies and percentages and a regression analysis performed to establish the relationships among the variables. The study findings indicated that a considerable number of the teachers (38.9\%) indicated that teacher's own perception of their own profession does not affect the teachers' job satisfaction and performance.
\end{abstract}

Keywords : Job satisfaction, Performance, Teachers, Teaching Profession, Perception.

\title{
Introduction
}

In the light of teachers' job dissatisfaction, DeBruyne [3] conducted a study to explore the relationship between teacher job satisfaction and job performance, and whether teacher attitudes about the job impacted their productivity on the job, in Wisconsin State. Findings suggested that teacher attitudes have a significant impact on the job performance of teachers and on the academic performance of their students.

A study by Caprara et al. [2] examined teachers' self-efficacy beliefs as determinants of their job satisfaction and students' academic achievement. Questionnaires were administered to over 2000 teachers in 75 Italian junior high schools to assess self-efficacy beliefs and their job satisfaction. The researchers also collected student's grades of two consecutive years. Structural equation modelling analyses corroborated a conceptual model in which teachers' personal efficacy beliefs affected their job satisfaction and students' academic achievement, controlling previous levels of achievement.

Similarly, Huysman [5] analyzed teachers' perceptions affecting job satisfaction in one small, rural Florida school district. This mixed methods study included a self-administered survey of Likert-scale items measuring 20 factors for job satisfaction, individual semi-structured interviews and focus groups. Several issues related to dissatisfaction not presented in previous studies surfaced. For example, participants reported a feeling of being unappreciated. This perception was influenced by the collective bargaining process which empowered local teachers to feel they were denied respect and that non-local faculty members fuelled unhealthy competition among them. The researchers recommended that leaders need to consider the concerns of home grown teachers in order to positively influence teacher retention, teacher quality, student achievement, and school climate.

In his study, Gardenhour [4] investigated teacher perceptions of their empowerment among 600 teachers from six school systems in the Northeast Tennessee region. The Psychological Empowerment Instrument was used to survey the sample. The findings showed that teacher empowerment, which also entailed servant leadership, is influenced by organizational structure, relationships, communication, conflict resolution, emotional intelligence, motivation, job satisfaction and transformational leadership. Findings suggested that experienced teachers had a higher level of empowerment than newer teachers in the profession. More so, it was evident that gender and level of education did little to influence teacher empowerment in schools.

There are however limited studies that having been conducted in regard to how teacher's own perception of their own profession affects their job satisfaction and performance. Therefore, this study sought to examine how teachers' own perception of their profession affects their job satisfaction and performance in Yei Town, South Sudan. 


\section{Methodology}

The study was carried out among private schools in Yei Town, South Sudan. According to Kerlinger, [7], a research design is the plan, structure and strategy of investigation conceived so as to obtain answers to research questions and control variance. This study employed a survey design in which quantitative data was collected. The target population for the study involved 10 private primary schools out of which 10 head teachers and 100 teachers participated.

Sampling is the procedure used to identify individual items to be studied. The teachers were selected through simple random sampling ensuring unbiasedness while from each school, one Principal was considered. Researchers such as Mugenda \& Mugenda [8] have stated that sample size for descriptive studies should be between 10 percent and 20 percent of the population. However, Kasomo [6] recommends that researchers should use the largest sample possible because statistics calculated from a large sample are more accurate. In order to provide for equal chance for every member in the school to be included, simple random sampling was used. The total sample size included 10 head teachers and a random sample of 100 teachers from each of the 10 private primary schools giving a total of 110 respondents.

A Self-administered, closed ended questionnaire was used for the study because it had the ability to limit inconsistency and save time [1]. Questionnaires were the most preferred method of data collection in this study because they produce normative data important for analysis. Collected data was analysed and presented in frequencies and percentages.

\section{Results and Discussion}

This study sought to establish teacher's own perception of their own profession and if this perception affected their job satisfaction and performance. By affirming (Yes) or negating (No), the respondents were asked to indicate if teacher's perception of their own profession affects their job satisfaction and performance. The results are as shown in Figure 1.

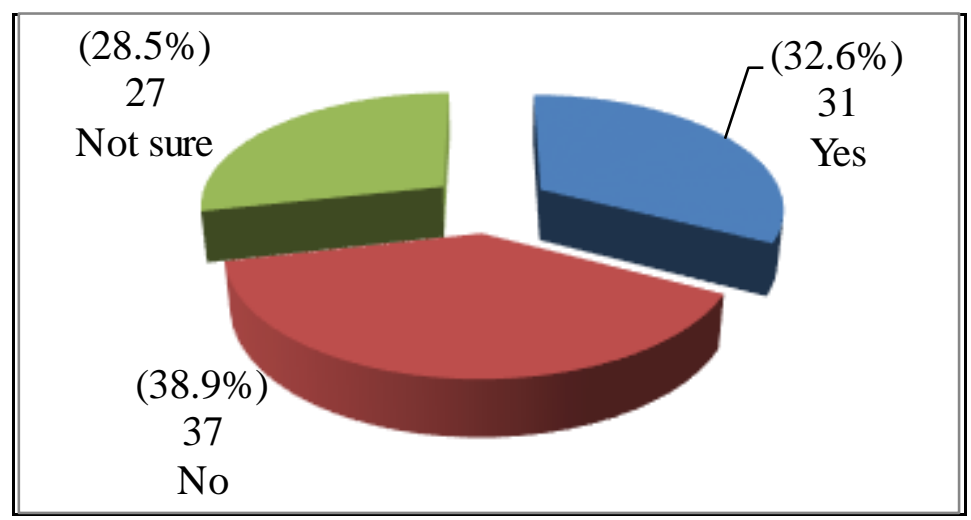

Figure 1. Teachers' own perception of their profession affects job satisfaction and performance

A considerable number of the teachers (38.9\%) indicated that teacher's own perception of their own profession does not affect the teachers' job satisfaction and performance. Whereas almost a third of them $(32.6 \%)$ indicated that indeed teacher's own perception of their own profession affects the teachers' job satisfaction and performance. The rest of them $(28.5 \%)$ were undecided. This study is in line with the works of DeBruyne [3] and Caprara et al. [2]. where their findings suggested that teacher attitudes and personal efficacy beliefs have a significant impact on the job performance of teachers and also the academic performance of their students. The current findings could be attributed to the fact that besides the perception of teachers on the teaching profession, there are other factors influencing job satisfaction and performance such as pay, working conditions, management and 
teacher training and development among others. Their perception of the teaching profession was therefore not seen as to affect job satisfaction as such.

To have a deeper understanding if teacher's own perception of their own profession affects the teachers' job satisfaction and performance, various aspects of how teachers perceive the teaching profession were presented and respondents were asked to indicate their extent of agreement with the statements. This is presented in Table 1 .

Table 1. How teachers' perception in regards to their profession influence their job satisfaction and performance

\begin{tabular}{|c|c|c|c|c|c|c|c|c|c|c|}
\hline \multirow[t]{2}{*}{ Statement } & \multicolumn{2}{|l|}{$\mathbf{S A}$} & \multicolumn{2}{|l|}{$\mathbf{A}$} & \multicolumn{2}{|l|}{$\mathbf{N}$} & \multicolumn{2}{|l|}{ D } & \multicolumn{2}{|l|}{ SD } \\
\hline & $\mathbf{F}$ & $(\%)$ & $\mathbf{F}$ & $(\%)$ & $\mathbf{F}$ & $(\%)$ & $\mathbf{F}$ & $(\%)$ & $\begin{array}{l}\mathbf{F} \\
(\%)\end{array}$ & \\
\hline $\begin{array}{l}\text { No one tell me that } \\
\text { am a good teacher }\end{array}$ & 20 & 21.1 & 14 & 14.7 & 18 & 18.9 & 43 & 45.3 & - & - \\
\hline $\begin{array}{l}\text { Teaching provides } \\
\text { for a secure future }\end{array}$ & 34 & 35.8 & 39 & 41.1 & 13 & 13.7 & 9 & 9.5 & - & - \\
\hline $\begin{array}{l}\text { I am afraid of } \\
\text { losing my teaching } \\
\text { job }\end{array}$ & 36 & 37.9 & 12 & 12.6 & 12 & 12.6 & 35 & 36.8 & - & - \\
\hline $\begin{array}{l}\text { My students } \\
\text { respect me as a } \\
\text { teacher }\end{array}$ & 47 & 49.5 & 26 & 27.4 & 20 & 21.1 & 2 & 2.1 & - & - \\
\hline $\begin{array}{l}\text { Teaching is very } \\
\text { interesting work }\end{array}$ & 45 & 47.4 & 29 & 30.5 & 11 & 11.6 & 10 & 10.5 & - & - \\
\hline $\begin{array}{l}\text { Teaching } \\
\text { discourages } \\
\text { originality }\end{array}$ & 19 & 20.0 & 11 & 11.6 & 21 & 22.1 & 44 & 46.3 & - & - \\
\hline $\begin{array}{l}\text { I never feel secure } \\
\text { in my teaching job }\end{array}$ & 16 & 16.8 & 15 & 15.8 & 15 & 15.8 & 49 & 51.6 & - & - \\
\hline
\end{tabular}

A substantial number of the teachers $(45.3 \%)$ disagreed to the statement that No one tells them that they are good teachers. However, $35.8 \%$ of them agreed to the statement. This finding is linked to the element of teachers being appreciated for their work. Recognition is a very important element and at least every teacher will want to be recognized for their work and appreciate the teaching profession. Based on the findings however, while majority of the teachers are recognized, still a number of them go unnoticed but this to a very small extend affects their performance.

When asked if teaching provides a secure future, a considerable number of the respondents $(41.1 \%)$ agreed to that statement. Moreover, $35.8 \%$ of them strongly agreed with the statement. A large percentage in this study perceives the teaching profession as that which provides them a secure future. This aspect is therefore less likely to affect their job satisfaction and consequent performance.

In response to whether the teachers are afraid of losing their teaching job, slightly more than half $(50.5 \%)$ of the respondents either strongly agreed or agreed with the statement. On the other hand, $36.8 \%$ of them disagreed with the statement. It is clear that given the circumstance in the teaching profession, most teachers are afraid to lose their job. Job security is a key element that contributes to the performance of teachers in schools and satisfaction. Private school unlike public schools, do not provide assurance of the teachers to work in a school given the inevitable board decisions to hire and fire. Teachers therefore may face the challenge of being replaced any time if they underperform.

Majority $(76.9 \%)$ of the teachers either strongly agreed or agreed with the statement that their students respect them as teachers. However, $21.1 \%$ of them were not sure if they are respected by their 
students as teachers. This may be an indication of lack of a strict engagement of teacher-student relationships which may undermine the respect students have for a teacher. However, most teachers portrayed respect by their students hence maintaining good teacher-student relationships. This is most likely to improve their job satisfaction and performance.

A significant figure of the respondents (47.4\%) strong agreed that teaching is a very interesting job. This was further supported by $(30.5 \%)$ of them who agreed with the statement. In response to whether teaching discourages originality, a considerable number of teachers $(46.3 \%)$ disagreed to the statement. Nevertheless, $31.6 \%$ strongly agreed and agreed to the same statement while the rest were undecided.

In regards to the statement 'I never feel secure in my teaching job', slightly more than a half of the employees (51.6\%) disagreed. On the other hand, almost a third of them (32.6\%) either strongly agreed or agreed with the statement.

\section{Conclusion}

A considerable number of the teachers (38.9\%) indicated that teacher's own perception of their own profession does not affect the teachers' job satisfaction and performance. Positive responses were found from certain aspects of how teachers perceive their teaching profession. Interestingly, dissatisfied teachers indicated teaching discourages originality, whereas others stated that they don't feel secure in a teaching profession. This leads the authors to believe that the impetus for satisfied teachers is to have a certain level of skills in regards to their qualification.

\section{References}

1. Amin, M. (2004). Foundations of Statistical Inference for Social Science Research. Kampala, Uganda: Makerere University.

2. Caprara, G. V., Barbaranelli, C., Steca, P., \& Malone, P. S. (2006). Teachers' Self-efficacy Beliefs as Determinants of Job Satisfaction and Students' Academic Achievement: A Study at the School Level. Journal of School Psychology, 44, 473-490.

3. DeBruyne, J. (2001). The Relationship between Teacher Job Satisfaction and Job Performance and Whether Teacher Attitudes About the Job Impacted Their Productivity on the Job in Wisconsin State, Research Journal of Education. Accessed in May, 2016. Google Scholar.

4. Gardenhour, C. R. (2008). Teachers Perceptions of Empowerment in Their Work Environments as Measured by the Psychological Empowerment Instrument. Unpublished Doctorate Dissertation, East Tennessee State University, U.S.A.

5. Huysman, J. (2008). Teachers' Perceptions Affecting Job Satisfaction in One Small, Rural Florida School District. Rural Educator, 29(2), 31-38.

6. Kasomo, D. (2007). Research Methods in Humanities and Education. Eldoret: Zapf Chancery.

7. Kerlinger, F. (1978). Foundations of Behavioral Research. Delhi, India: Holt, Rinehart and Winston.

8. Mugenda, O., \& Mugenda, A. (1999). Research Methods: Qualitative and Quantitative Approaches. Nairobi: Acts Press. 